\title{
Shoreline Evolution of Lagoon Sandy Spits and Adjacent Beaches, Lagoa dos Patos, Brazil
}

\author{
Inaiê Malheiros Miranda ${ }^{\dagger *}$, Elírio Ernestino Toldo, $\mathrm{Jr}^{\ddagger}{ }^{\ddagger}$, \\ Antonio Henrique da Fontoura Klein ${ }^{\S}$, and Guilherme Vieira da Silva ${ }^{\dagger \dagger}$
}

${ }^{\dagger}$ Programa de Pós-graduação em Geociências Universidade Federal do Rio Grande do Sul Porto Alegre 91501, Brazil

${ }^{\S}$ Laboratório de Oceanografia Costeira Coordenadoria Especial de Oceanografia/CFM Universidade Federal de Santa Catarina Campus Universitário Florianópolis 88040, Brazil
${ }^{\ddagger}$ Centro de Estudos de Geologia Costeira e Oceânica Instituto de Geociências

Universidade Federal do Rio Grande do Sul

Porto Alegre 91501, Brazil

${ }^{\dagger \dagger}$ Griffith Centre for Coastal Management

Griffith University Building G51

Gold Coast Campus

Queensland 4222, Australia

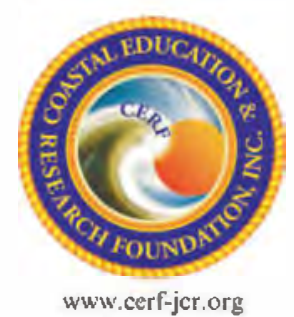

www.cerf-jer.org

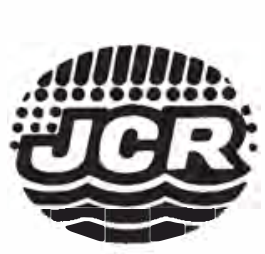

www.JCRonline.org

\begin{abstract}
Miranda, I.M.; Toldo, E.E., Jr.; Klein, A.H.F., and Vieira da Silva, G., 2019. Shoreline evolution of lagoon sandy spits and adjacent beaches, Lagoa dos Patos, Brazil. Journal of Coastal Research, 35(5), 1010-1023. Coconut Creek (Florida), ISSN 0749-0208.

The development of lagoon sandy spits is dependent on sediment supply (mainly through longshore transport) and is often related to erosion of updrift beaches under high-angle waves. This paper provides an understanding of the short- to medium-term shoreline evolution of three symmetrical lagoon sandy spits and the related erosion of the adjacent bay beaches of Lagoa dos Patos, Brazil. To do so, two of the most widely used methods to quantify shoreline changes were applied: the transects-from-baseline method and the change polygon method. A historical analysis of the shoreline movement of approximately three decades (1984-2013), was carried out, aiming to track the source of sediments to the spits. Alternate phases of shoreline stability, deposition, and recession (less frequent) in short time intervals (years) showed correlation with the El Niño-Southern Oscillation and Southern Annular Mode indexes. Shoreline stability along beaches in the medium term (60.4\% of Arambare and $73.9 \%$ of Graxaim beaches, by the linear regression rate calculation), together with the very low average shoreline change rate of $+0.7 \mathrm{~m} \mathrm{y}^{-1}$ found using both methods, demonstrates that the sediment supply to the spits has been significantly reduced in the past three decades. Furthermore, the large-scale subaqueous portions of the spits are under wave-induced sedimentary reworking accompanied by the up-building of sandbanks from the submerged bars, followed by its landward migration and merging to the spit's shoreline. These results suggest that the spits of Lagoa dos Patos have their growth limited once the amount of sediment supply has been significantly reduced.
\end{abstract}

ADDITIONAL INDEX WORDS: Lagoon spit evolution, Landsat images, DSAS, change polygon method.

\section{INTRODUCTION}

The spits analyzed in this research correspond to nearly symmetrical morphological features in a simple cuspate form, associated with large-scale submerged sandbars. They are attached at one end to the mainland and extend approximately half of the lagoon width to deeper water. These type of spits used to be classified as "cuspate spits," a nomenclature first suggested by Shepard (1952) and adopted in the studies of Fisher (1955) in Koozata lagoon, St. Lawrence Island, Alaska; Zenkovitch (1959) in Chukchi Peninsula, Russia; Rosen (1975) in Nantucket Island, Massachusetts; and a posteriori by Ashton et al. (2009) in the planform coastline evolution model of sandy spits in fetch-limited elongated lagoon waterbodies. Rosen $(1975,90)$ differentiates (1) cuspate spits from (2) cuspate forelands as: (1) "a cuspate projection of a beach into a body of water with fetch limited by basin shape, representing

DOI: 10.2112 /JCOASTRES-D-18-00092.1 received 5 July 2018; accepted in revision 27 December 2018; corrected proofs received 8 February 2019; published pre-print online 6 March 2019.

*Corresponding author: inaiemalheiros@gmail.com

${ }^{\odot}$ Coastal Education and Research Foundation, Inc. 2019 a reorientation of the shoreline to dominant wave-approach" and (2) "a cuspate projection of a beach with no fetch limitations, representing reorientation of the shoreline to dominant wave-approach." Previously, they also have been referred to as "V-bar" and "V-terrace" by Gilbert (1885).

These types of landforms correspond to accumulating cuspate forms, developed in microtidal areas and generated by longshore processes as the result of waves approaching a shoreline at a high angle, and include beach cusps, beach protuberances, looped spits, cuspate spits, and cuspate forelands (Rosen, 1975). They are formed from a variety of materials of varying grain sizes, from fine sands to boulders (Randazzo, Jackson, and Cooper, 2015). The stability of spits is, very often, the result of a fragile equilibrium between the availability of sediments and the hydrodynamics, and because of the complex interactions between the processes shaping such geomorphologic features, the investigation is difficult and requires separate analyses for each of the processes (Dan et $a l ., 2011)$. The continuous growth of spits is known to be closely related to the availability of sediment supply transported by longshore currents toward the spit ends (Ashton, Murray, and 
Arnault, 2001; Ashton, Nienhuis, and Ells, 2016; Bouchette et al., 2014; Kraus, 1999; Kumar, Deepika, and Jayappa, 2013; Kumar, Narayana, and Jayappa, 2010; Petersen, Deigaard, and Fredsoe, 2008; Rosen, 1975; Uda, 2015; Zenkovitch, 1959). Following this well-accepted statement, the present study argues that the analyzed lagoon sandy spits have reached a development level characterized by a reduction in sediment supply from the erosion of associated beaches, thus limiting their growth. Therefore, the goal of this paper is to assess the shoreline evolution of spits and their adjoining beaches at an event to engineering scale, aiming to investigate whether the expected low rates of shoreline retreat along the bay beaches are observed.

\section{Study Area}

Lagoa dos Patos is a very large and shallow barrier lagoon located at the coastal plain of Rio Grande do Sul state, in the southern Brazilian coast, with NE-SW orientation. It has length and width of about 240 and $40 \mathrm{~km}$, respectively, and covers an area of approximately $10,000 \mathrm{~km}^{2}$, with an average depth of almost $6 \mathrm{~m}$ and mean tidal amplitude of $0.45 \mathrm{~m}$ (Toldo, Almeida, and Corrêa, 2003). The geological evolution of the coastal plain of Rio Grande do Sul was controlled by Quaternary glacioeustatic sea level fluctuations responsible for the construction of four barrier lagoon depositional sequences, named from the youngest to the oldest as barrier lagoon systems I, II, III, and IV (Tomazelli, Dillenburg, and Villwock, 2004). System I is only exposed along the inner western shore of the lagoon and consists mostly of small, coalescing alluvial fans, whereas the long barrier that separates Lagoa dos Patos from the ocean is composite and includes both Pleistocene (system III) and Holocene (system IV) parts (Toldo et al., 2000).

The weather of Rio Grande do Sul state is highly seasonal and strongly related to the large-scale pressure systems of the polar anticyclone in autumn and winter and the Atlantic anticyclone in summer and spring (Hasenack and Ferraro, 1989). The NE winds are dominant throughout the year, with southerly winds becoming more important during autumn and winter when the frontal systems are more frequent and the prevailing NE wind rotates to the southern quadrant (Moller $e t$ al., 1996).

The lagoon receives fresh water from $170,000 \mathrm{~km}^{2}$ of watershed, mostly from the Guaiba River at the Jacuí Delta at the NW end of the lagoon, with a much smaller contribution from the Camaquã River (Toldo et al., 2000). In terms of sediment sources, Guaíba River contributes mainly mud to the lagoon because most of the sand is trapped at its large estuary (Toldo, Almeida, and Corrêa, 2003).

Lagoa dos Patos presents two distinct morphological and sedimentological bottom types: The first unit is composed predominantly of quartz sand and corresponds to the lagoon margin, where the spits are the most prominent features, extending approximately up to the 5-m isobath, and the second unit is composed predominantly of silty-clayey sediments and corresponds to a nearly flat lagoon bottom, from the $\sim 5-\mathrm{m}$ isobaths to deeper portions of the waterbody (Toldo, 1991; Toldo et al., 2006). The emerged part of the sandy spits are marked by the border between the lagoon shoreline and the waterbody, and the submerged part of these features extends into the lagoon as submerged bars, accompanying the bathymetric curve of $1 \mathrm{~m}$ below the water surface to a depth of $5-6 \mathrm{~m}$ (Toldo, 1991).

This study is focused on the short- to medium-term shoreline evolution of three well-developed lagoon sandy spits (Dona Helena, Dona Maria, and Vitoriano) and two adjacent bay beaches, located on the central landward margin of Lagoa dos Patos (Figure 1). The subaqueous sandbars can reach lengths of about $20 \mathrm{~km}$ (Dona Maria spit), half of the lagoon width, being one of the longest spit features in lagoon waterbodies around the world. Similarly, Zenkovitch (1959) observed better development of "cuspate spits" in the central region of some lagoon systems on the northern shores of Chukchi Peninsula, Russia.

The morphology of the lagoon is marked by many "cells" or "pools" limited by shallow sandy spits, and the lagoon is connected to the ocean through a narrow channel of 1-2 km width and $20 \mathrm{~km}$ length (Moller et al., 1996).

Moller et al. (1996) showed that the tidal signal is of importance only near the exit to the ocean and is strongly attenuated as soon as it enters the Lagoa dos Patos inlet. Then, Fernandes et al. (2004) reinforced the previous studies, demonstrating that the single long and narrow inlet of Lagoa dos Patos acts as a natural hydraulic low-pass filter that reduces or eliminates tidal and subtidal effects inside the lagoon. Upstream, the main forcing effect controlling the dynamics of the system is generated by the local wind (Fernandes et al., 2004).

As demonstrated by Moller et al. (1996, 2001), the wind drives circulation through its local and nonlocal effects. The former effect is associated with the longitudinal wind (NE/SW) to force the set up/set down mechanism of oscillation (up to $1 \mathrm{~m}$ ) driving seaward/landward flows during periods of low river contribution, in which the midlagoon region (the study area) constitutes the nodal zone, whereas the latter effect is observed by water level variations caused by the Ekman transport mechanism, which is an important factor in water exchange with the continental shelf (Moller et al., 2001).

\section{METHODS}

Assessment of the short- and medium-term shoreline evolution was carried out by using the Landsat satellite images and two distinct approaches on the basis of a shoreline transect by the Digital Shoreline Analysis System (DSAS; Thieler et al., 2009) and an area analysis by the change polygon method (CPM; Smith and Cromley, 2012). The steps performed in this research are summarized in Figure 2 and described below.

\section{Image Preprocessing}

Landsat images were selected because of their multispectral characteristics and large temporal and spatial coverage. Thus, they provided a consistent dataset with the longest time series available to access the shoreline changes of the study area. The images cover almost three decades, including seven satellite images obtained by Landsat $5^{\mathrm{TM}}$ and Landsat 8 Operational Land Imager (OLI; Table 1) from the National Institute for Space Research of Brazil (INPE) and the U.S. Geological Survey. To correct the geometric distortion of the images, 33 


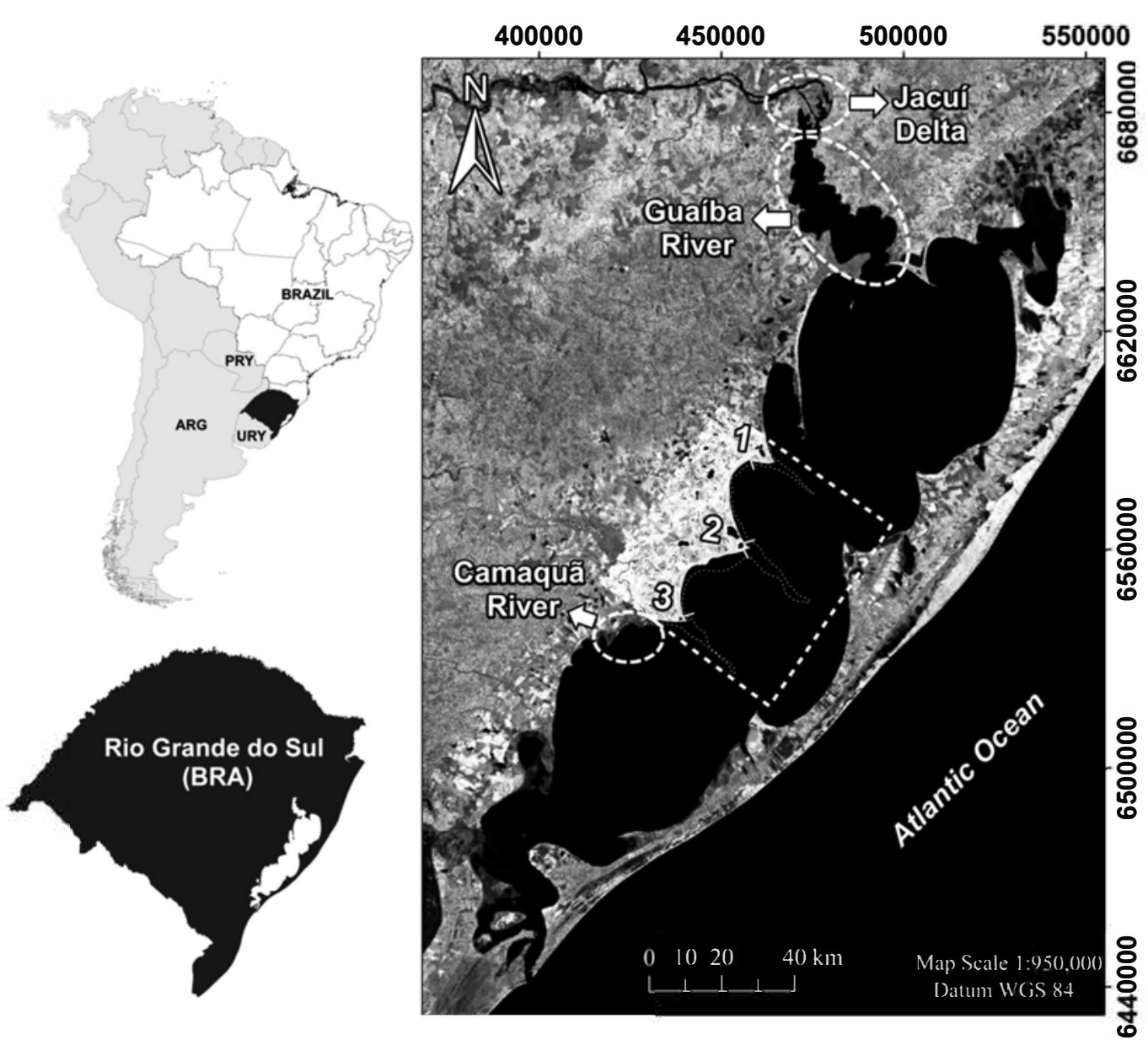

Figure 1. Study area covering the three analyzed lagoon sandy spits in the central landward margin of Lagoa dos Patos, indicated by (1) Dona Helena, (2) Dona Maria, and (3) Vitoriano, with the cross sections separating the spits from the bay beaches. The dashed contour lines indicate the 1-m below water surface isobathymetric line of the submerged spit bars and the dashed circles are the main tributaries of the system with their respective names. Image source: ESRI, DigitalGlobe, GeoEye, Earthstar Geographics, the National Centre for Space Studies (CNES)/Airbus DS, U.S. Department of Agriculture, U.S. Geological Survey, AeroGRID, IGN Spain, and the GIS User Community.

ground control points were acquired with the differential GPS Outback Lite system, and image georeferencing was performed by ArcGIS 10.1 software. The respective errors were calculated by the root mean square error equation (Table 1 ).

To estimate the uncertainty of the shoreline change rate $\left(U_{t}\right)$ the method proposed by Appeaning Addo, Jayson-Quashigah, and Kufogbe (2011) and Fletcher et al. (2012) was used. It assumes that the total uncertainty in the annualized shoreline change rate calculations is given by the square root of the sum of the squares of errors divided by the analyzed time period (Equation [1]):

$$
U_{t(\mathrm{~m} / \mathrm{y})}= \pm \frac{\sqrt{E_{\text {img1 }}^{2}+\ldots+E_{\text {imgn }}^{2}+E_{\mathrm{p}}^{2}}}{T}
$$

where, $E_{\text {img1 } 1}, \ldots, E_{\text {imgn }}$ are the image rectification errors (Table 1$), E_{\mathrm{p}}$ is the pixel error ( $30 \mathrm{~m}$ ), and $T$ is the time period. Such an approach carries the assumption that the component errors are normally distributed (Appeaning Addo, JaysonQuashigah, and Kufogbe, 2011; Appeaning Addo, Walkden, and Mills, 2008; Dar and Dar, 2009; Jonah et al., 2016).

The uncertainty related to the tidal range was not taken into account because the tidal signal is insignificant at the study area (Kjerve and Magil, 1989; Moller et al., 1996; Fernandes et al., 2004).

\section{Shoreline Indicator and Detection Technique Using Landsat Satellite Image}

The proxy for the delimitation of the shoreline position in the present study was the high water line, proposed by Pajak and Leatherman (2002), because it was consistent along the entire analyzed perimeter and easily detected in the data source, satisfying the necessary criteria (Crowell, Leatherman, and Buckley, 1991; Gens, 2010; Pajak and Leatherman, 2002; Vieira da Silva et al., 2016) for the delimitation of the shoreline position. 


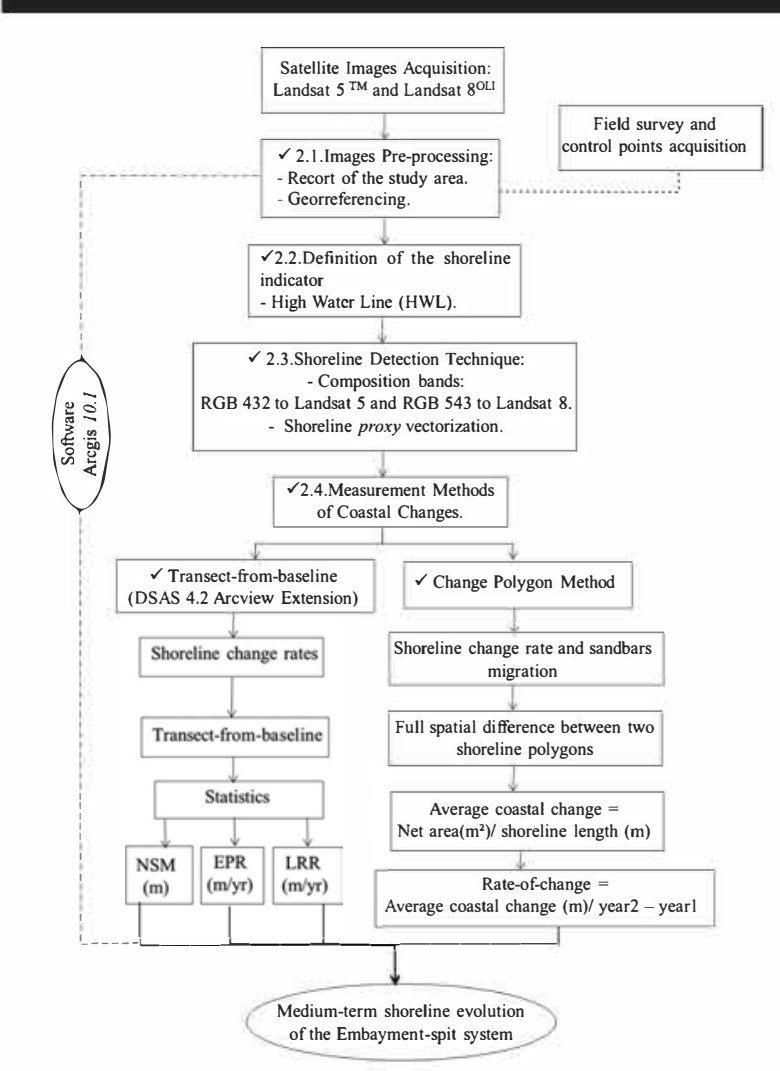

Figure 2. Flowchart showing the steps of the methodologies used in this work.

After various tests, it was found that the Landsat 5 red, green, blue (RGB) 432 composite and the corresponding 543 combination of Landsat 8 were best for delimiting the wet/dry boundary. By using these band combinations, the emerged sandy areas were easily identified by the color white because of the higher reflectance of the dry sand sediments in the visible region $(0.4-0.7 \mu \mathrm{m})$ and near infrared $(0.7-1.0 \mu \mathrm{m})$, whereas the sediments containing interstitial water had a clear bluegreenish color because of the different spectral response influenced by the target water. Similar spectral responses to suspended sediments and shallow waters was noticed by Alves, Amaro, and Vital (2003). This composite band also allowed the visualization of portions of the submerged sandbars and coastal vegetation (reeds), which were differentiated from the land by the increase in vegetation reflectance in the near infrared band (Landsat 5 TM band 4 and Landsat 8 OLI band 5).

\section{Transect-from-Baseline}

The analysis of shoreline changes was carried out through the transect-from-baseline method by using the DSAS 4.2 ArcGIS extension, developed by Thieler et al. (2009). To do so, 3301 shore-perpendicular transects were generated from a preestablished baseline, with a spacing distance of $25 \mathrm{~m}$ (covering $90.8 \mathrm{~km}$ ), whereby the following statistics were computed: net shoreline movement (NSM), end point rate (EPR), and linear regression rate (LRR). A detailed description of the statistics can be found in Crowell, Douglas, and Leatherman (1997); Crowell, Leatherman, and Buckley (1991); Fenster, Dolan, and Elder (1993); Galgano and Douglas (2000); and Thieler et al. (2009).

The NSM and EPR were applied to six time spans (19841988, 1988-1995, 1995-2001, 2001-2005, 2005-2009, and 2009-2013) to investigate the existence of cyclical trends through the measurement of coastal changes (Equations [2] and [3]). The LRR was used for the medium-term shoreline assessment, taking into account all available shoreline vectors:

$$
\begin{gathered}
\text { Average NSM }=\frac{\sum \text { NSM }}{n^{\circ} \text { transect }} \\
\text { Annual rate of change }=\frac{\text { Average NSM }}{\text { Time }(\mathrm{y})}
\end{gathered}
$$

Change Polygon Method (Smith and Cromley, 2012)

The CPM, developed by Smith and Cromley (2012), uses two different shorelines to construct a polygon topology based on the geometric assumption that area $=$ length $\times$ width. To do so, the shoreline vectors were converted to the polygon format and the subtraction between these two shoreline polygons resulted in a series of simple polygons representing: accretional areas, where the recent shoreline transpose the limits of the oldest shoreline; recessional areas, where the oldest shoreline transposes the boundary of the youngest shoreline; and without change or null, when the intersection between the polygons fell into the same area (Smith and Cromley, 2012). The subpolygons were then decomposed into positive (depositional) and negative (recessional) areas and summed to produce a total change estimate ( $\mathrm{A} f$, net area). The net area was then divided by one of the shoreline perimeters $(P)$, resulting in an average coastal change (Equation [4]) (Smith and Cromley, 2012):

\begin{tabular}{|c|c|c|c|c|c|c|c|}
\hline Acquisition Date & Water Level (m) & Satellites & Sensors & Bands & Electromagnetic Spectrum Range $(\mu \mathrm{m})$ & Spatial Resolution (m) & RMSE (m) \\
\hline 24 Apr 1984 & - & Landsat 5 & TM & 2 (green) & $0.52-0.60$ & 30 & 1.11 \\
\hline 14 Apr 1988 & 0.51 & & & 3 (red) & $0.63-0.69$ & 30 & 1.75 \\
\hline 7 Apr 1995 & 0.41 & & & 4 (near infrared) & $0.76-0.90$ & 30 & 1.18 \\
\hline 25 May 2001 & 0.84 & & & & & & 0.82 \\
\hline 18 Apr 2005 & 0.44 & Landsat 8 & OLI & 3 (green) & $0.525-0.600$ & 30 & 0.93 \\
\hline 13 Apr 2009 & 0.56 & & & 4 (red) & $0.630-0.680$ & 30 & 1.14 \\
\hline 27 Jun 2013 & 0.37 & & & 5 (near infrared) & $0.845-0.885$ & 30 & 1.28 \\
\hline
\end{tabular}

Table 1. Landsat satellite image date, average water level on the acquisition date, image details, and respective acquisition data and related errors.

Abbreviations: $T M=$ Thematic Mapper, $O L I=$ Operational Land Imager, $R M S E=$ root mean square error 


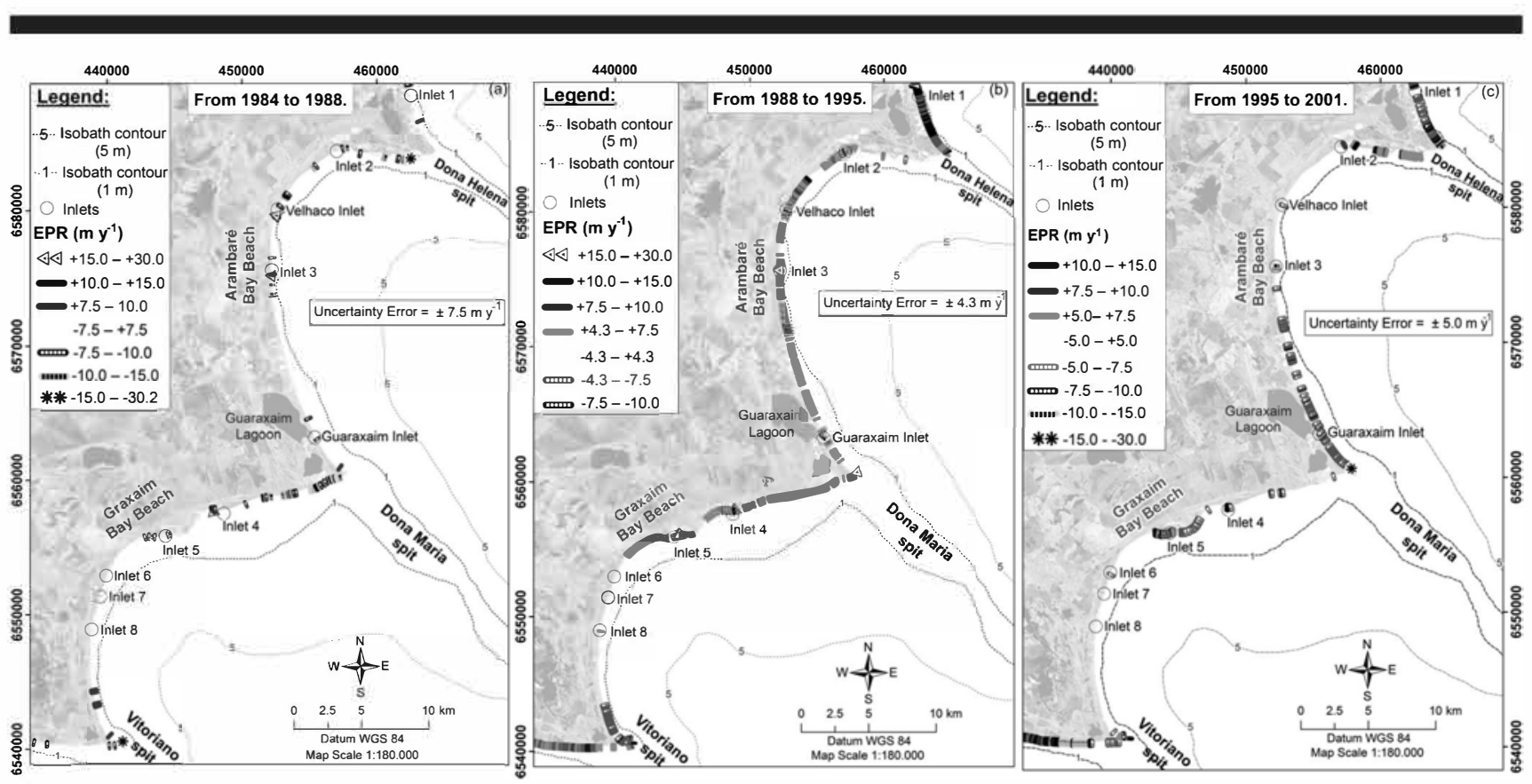

Figure 3. Shoreline change rates using the EPR statistic for time intervals (a) 1984-1988, (b) 1988-1995, and (c) 1995-2001. Image source: Landsat 5.

$$
D=\frac{\mathrm{A} f\left(\mathrm{~m}^{2}\right)}{P(\mathrm{~m})}
$$

The estimation of the net annual rate of change was then given by the ratio of the average coastal change $(D)$ and the time period between the two coastlines.

\section{RESULTS}

The results are described by short- and medium-term shoreline change assessments according to the aforementioned methodologies.

\section{Short-Term Shoreline Evolution (End Point Rate)}

Stability, depositional, and, less frequently, recessional trends were observed in short time intervals (years) (Figures 3 and 4). The uncertainty error estimation for the shoreline change rates in the short-term analysis ranged from \pm 4.3 up to $\pm 7.5 \mathrm{~m} \mathrm{y}^{-1}$.

From 1984 to 1988 the bay beach shorelines were mainly stable, in which $93 \%$ of Arambaré and $88.2 \%$ of Graxaim were within the uncertainty error $\left( \pm 7.5 \mathrm{~m} \mathrm{y}^{-1}\right)$. Furthermore, $3.8 \%$ of Arambaré and $5.3 \%$ of Graxaim shorelines experienced recession rates ranging from -7.5 to $-10 \mathrm{~m} \mathrm{y}^{-1}$, mainly at the northern coast of the embayment. The highest retreat rates were observed at the south margin of Dona Helena spit ( -18.2 $\left.\mathrm{m} \mathrm{y}^{-1}\right)$ and at the distal end of Vitoriano spit $\left(-30.2 \mathrm{~m} \mathrm{y}^{-1}\right)$ (Figure 3a). The former is not an indication of erosion but the change in direction of the distal end. Also, high depositional rates occurred next to the inlet of Velhaco River $\left(+16.0 \mathrm{~m} \mathrm{y}^{-1}\right)$ and at the inlets of irrigation channels $3\left(+27.7 \mathrm{~m} \mathrm{y}^{-1}\right)$ and 4 $\left(+19.1 \mathrm{~m} \mathrm{y}^{-1}\right)$, whereas the southern margin of inlet 5 retreated with rates ranging from $-10.0 \mathrm{~m}$ up to $-14.9 \mathrm{~m} \mathrm{y}^{-1}$.
From 1988 to 1995, Arambaré bay beach showed the predominant occurrence of shoreline progression (51.0\%), ranging from +4.3 to $+7.5 \mathrm{~m} \mathrm{y}^{-1}$, followed by $37.2 \%$ stable values $\left( \pm 4.3 \mathrm{~m} \mathrm{y}^{-1}\right)$, whereas $59.4 \%$ of Graxaim bay beach was stable, followed by $31.3 \%$ prograding shoreline on the northcentral sector of the embayment, ranging from +4.3 to $+7.5 \mathrm{~m}$ $\mathrm{y}^{-1}$. Moreover, very high depositional rates were observed at inlets $4\left(+20.0 \mathrm{~m} \mathrm{y}^{-1}\right)$ and $5\left(+17.9 \mathrm{~m} \mathrm{y}^{-1}\right)$, along with the prolongation of Dona Maria $\left(+18.4 \mathrm{~m} \mathrm{y}^{-1}\right)$ and Dona Helena $\left(+11.3 \mathrm{~m} \mathrm{y}^{-1}\right)$ spits (Figure 3b). Despite de general trend of shoreline progradation during this time period, the updrift coast of Vitoriano spit $(\sim 3 \mathrm{~km})$ retreated with rates of $-4.3 \mathrm{~m}$ $\mathrm{y}^{-1}$ to $-6.6 \mathrm{~m} \mathrm{y}^{-1}$, while its distal end prograded at $+13.7 \mathrm{~m} \mathrm{y}^{-1}$. At the same time, the migration of an adjacent sandbank could be observed.

From 1995 to 2001, 77.8\% and 90.8\% of Arambaré and Graxaim shorelines, respectively, were stable $\left( \pm 5.0 \mathrm{~m} \mathrm{y}^{-1}\right)$, followed by $19.3 \%$ of Arambaré coastline experiencing retreat rates ranging from -5.0 to $-7.5 \mathrm{~m} \mathrm{y}^{-1}$, predominantly on the southern coast of the embayment, whereas, on the northern extremity of the beach $0.76 \%$ shoreline progradation was observed (Figure 3c). Graxaim bay beach presented a smaller percentage of shoreline recession $(6.7 \%)$, with rates ranging from -5.0 to $-7.5 \mathrm{~m} \mathrm{y}^{-1}$, predominantly occurring at the inflection point of the shoreline (in the surroundings of inlet 5). Also, punctual depositional values occurred at the mouths of inlets $4\left(+10.9 \mathrm{~m} \mathrm{y}^{-1}\right)$ and $5\left(+5.13\right.$ to $\left.+6.6 \mathrm{~m} \mathrm{y}^{-1}\right)$ (Figure 3c). Maximum shoreline retreat rates of $-29.3 \mathrm{~m} \mathrm{y}^{-1}$ were observed at the distal edge of Dona Maria spit, while the distal edge of Vitoriano spit showed a high depositional rate $\left(+12.8 \mathrm{~m} \mathrm{y}^{-1}\right)$ (Figure 3c). The high depositional rate of the former is due to the merging of the adjacent sandbank. 


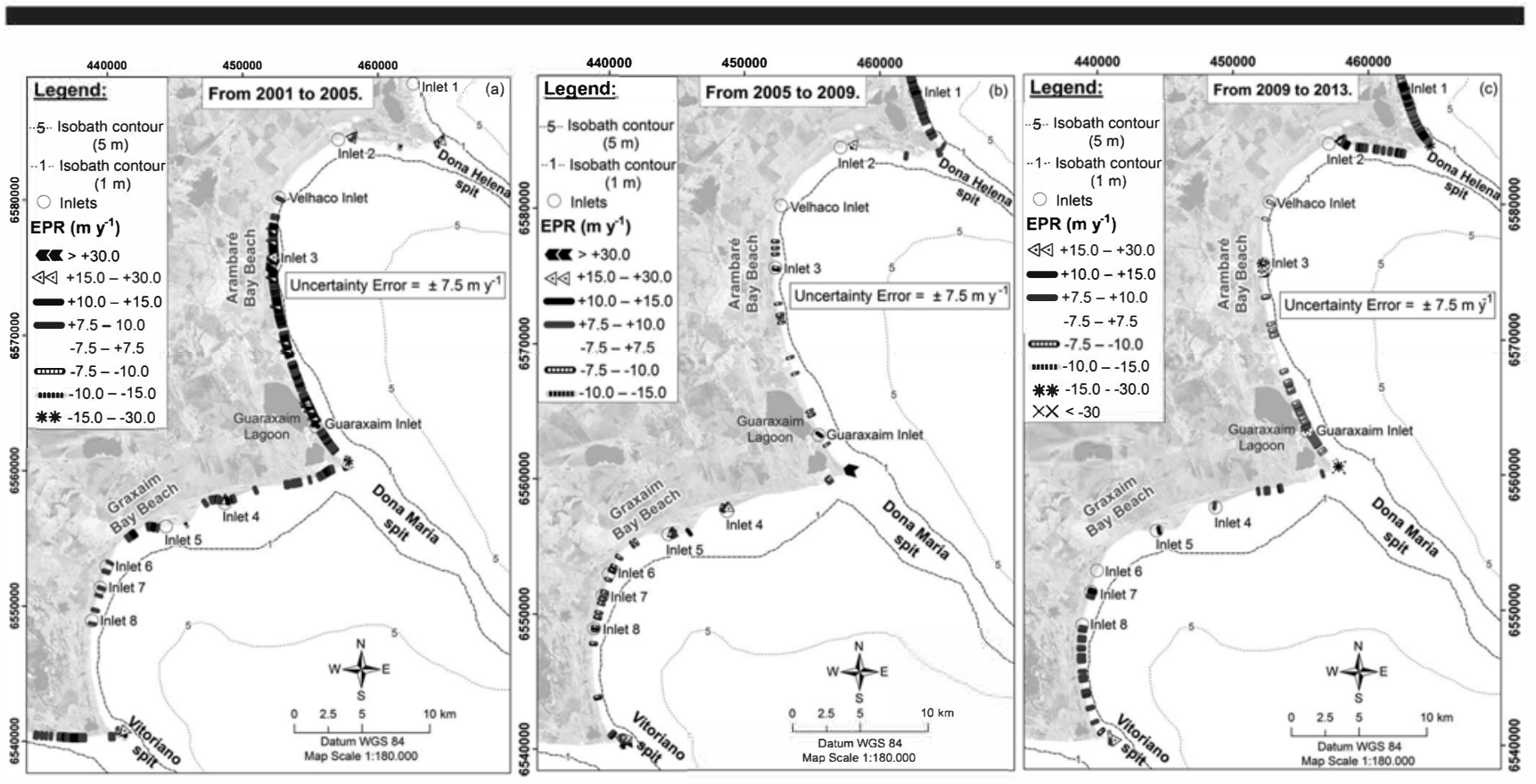

Figure 4. Shoreline change rates using the EPR statistic for time intervals (a) 2001-2005, (b) 2005-2009, and (c) 2009-2013. Image source: Landsat 5.

Between 2001 and 2005, 87.3\% and 44.0\% of Graxaim and Arambaré beaches, respectively, showed a stable trend $( \pm 7.5 \mathrm{~m}$ $\left.\mathrm{y}^{-1}\right)$. Shoreline progradation was observed $55.9 \%$, mainly along the central and southern coast of Arambaré, ranging from +7.5 $\mathrm{m} \mathrm{y}^{-1}$ up to a peak of $+20.09 \mathrm{~m} \mathrm{y}^{-1}$ next to inlet 3 (Figure $4 \mathrm{a}$ ). Graxaim bay beach, on the other hand, experienced less shoreline progradation, with $12.6 \%$ of the coastline and rates ranging from $+7.5 \mathrm{~m} \mathrm{y}^{-1}$ up to a peak of $+17.2 \mathrm{~m} \mathrm{y}^{-1}$ next to inlet 4. The recurved Vitoriano spit migrated landward $\left(-21.1 \mathrm{~m} \mathrm{y}^{-1}\right)$ and elongated northward (mainly) and southward. Also, a very high progradation rate of $+48.9 \mathrm{~m} \mathrm{y}^{-1}$ was observed at the southern edge of this spit. The northern spit (Dona Helena) also showed a high progradation rate at its eastern edge, $+19.9 \mathrm{~m}$ $\mathrm{y}^{-1}$, and the Dona Maria spit showed a retreat rate of $-17.8 \mathrm{~m}$ $\mathrm{y}^{-1}$ because of the southward migration of its distal end toward the approaching sandbank.

Another period marked by the predominant shoreline stability trend was between 2005 and 2009, corresponding to $94.7 \%$ of Arambaré and $89.2 \%$ of Graxaim $\left( \pm 7.5 \mathrm{~m} \mathrm{y}^{-1}\right)$. Moreover, $4.3 \%$ and $7.9 \%$ of Arambaré and Graxaim, respectively, experienced recession rates ranging from -7.5 to $-10 \mathrm{~m}$ $\mathrm{y}^{-1}$. The landward migration of Vitoriano spit $\left(-12.7 \mathrm{~m} \mathrm{y}^{-1}\right)$ continued during this time span, together with sediment deposition at its southern edge, with rates of +25.6 and +38.7 $\mathrm{m} \mathrm{y}^{-1}$. The east edge of Dona Maria spit was marked by a very high deposition rate of $+59.4 \mathrm{~m} \mathrm{y}^{-1}$ as a result of the merging of the adjacent sandbank (Figure 4b). Representative sediment input from the sandbar to the shoreline was also experienced by Vitoriano spit between 1995 and 2001. Moreover, localized high depositional rates were observed at the east margin of Lagoa do Graxaim inlet $\left(+12.4 \mathrm{~m} \mathrm{y}^{-1}\right)$ and $+20.5 \mathrm{~m} \mathrm{y}^{-1}$ and $+24.0 \mathrm{~m} \mathrm{y}^{-1}$ next to inlet 4.
The dominant trend to general stability continued during the time interval from 2009 to 2013, during which $80.9 \%$ of Arambaré and $89.5 \%$ of Graxaim were stable. However, a considerable occurrence of shoreline retreat (15.7\%), ranging from -7.5 to $-10.0 \mathrm{~m} \mathrm{y}^{-1}$ along the southern coast of the Arambaré, was observed, whereas the northern extremity of the embayment (south margin of Dona Helena spit) was marked by depositional values ranging from $+7.5 \mathrm{~m} \mathrm{y}^{-1}$ up to a maximum of $+30.1 \mathrm{~m} \mathrm{y}^{-1}$ at the accentuated shoreline curvature (Figure 4c). Moreover, a high retreat rate of $-19.6 \mathrm{~m}$ $\mathrm{y}^{-1}$ was observed at the left margin of Lagoa do Graxaim inlet. The distal end of Dona Helena spit retreated $\left(-25.4 \mathrm{~m} \mathrm{y}^{-1}\right)$, as well as the distal end of Dona Maria spit $\left(-57.5 \mathrm{~m} \mathrm{y}^{-1}\right)$. Sediment accumulation continued occurring at the southern edge of Vitoriano spit, but with lower rates, ranging from $+8.7 \mathrm{~m}$ $\mathrm{y}^{-1}$ up to a maximum of $+22.1 \mathrm{~m} \mathrm{y}^{-1}$.

Graxaim embayment was marked by depositional rates of $8.8 \%$, ranging from +7.5 to $+10.0 \mathrm{~m} \mathrm{y}^{-1}$, mainly concentrated along the southern part of the beach, with peak values at inlet 7 ranging from +10.1 up to $+11.5 \mathrm{~m} \mathrm{y}^{-1}$ and at inlet 5 of $+13.0 \mathrm{~m}$ $\mathrm{y}^{-1}$ (Figure 4c).

Overall, the bay beaches showed the prevailing occurrence of stable values. However, alongshore variability with intercalated periods of recession and deposition were observed in short time intervals (years), and the very high values of shoreline progradation and retreat were localized and mainly situated at the mouths of the irrigation channels and at the spit ends, demonstrating its accentuated dynamic.

\section{Change Polygon Method}

The rates of shoreline movement provided by the CPM were very similar to the rates from the EPR method (Figure 5; Table 2). 


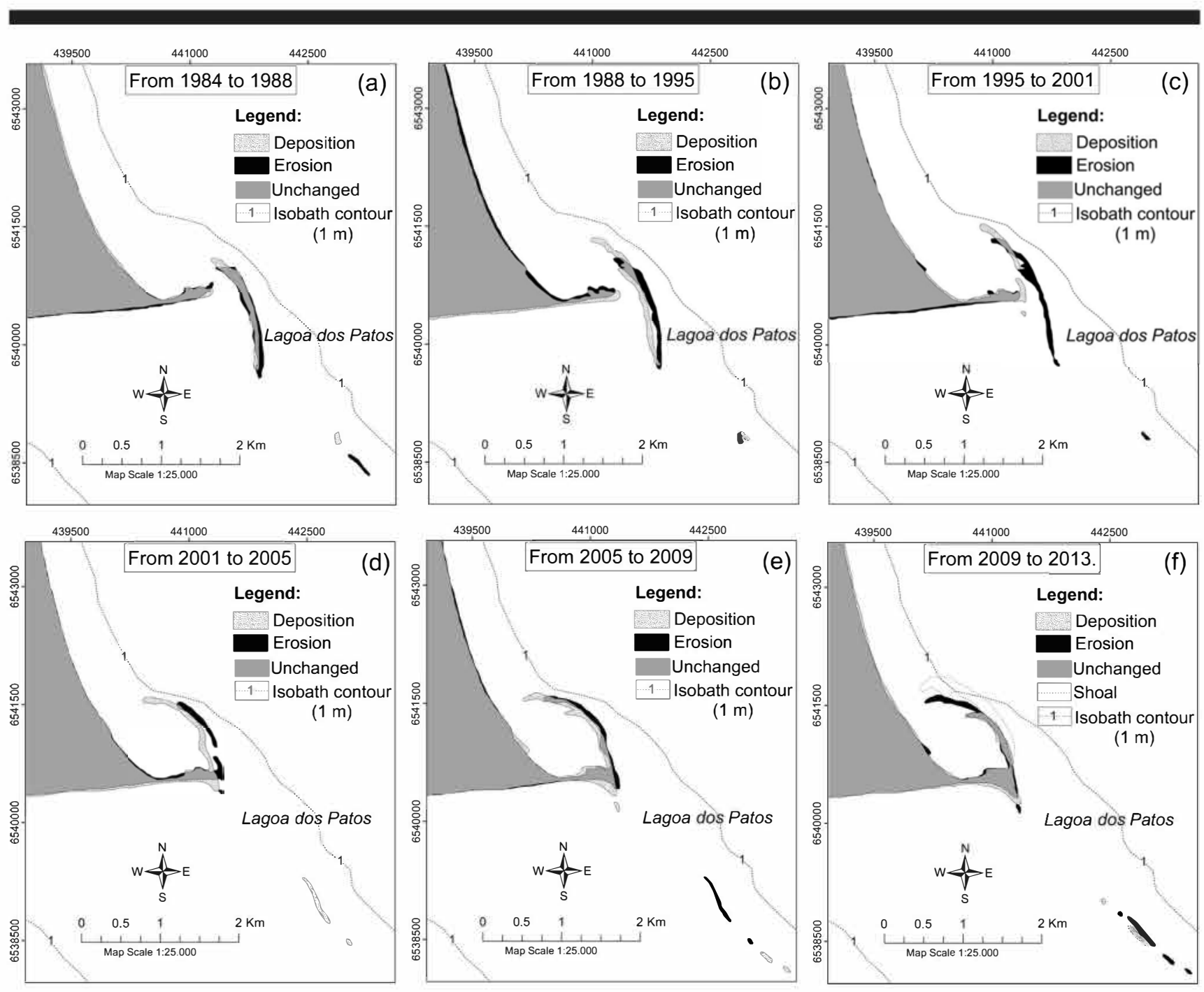

Figure 5. Analysis of the recent geomorphological evolution of the Vitoriano spit, highlighting the sedimentary reworking (cannibalism) of the submerged feature, through the up-building process of sandbanks from the large-scale submerged sandbars, followed by its landward migration and merging to the spit's shoreline during (a) 1984-1988, (b) 1988-1995, (c) 1995-2001, (d) 2001-2005, (e) 2005-2009, and (f) 2009-2013.

From 1984 to 2013, the CPM showed a mean shoreline movement of $+0.7 \mathrm{~m} \mathrm{y}^{-1}$, within the annualized long-term error of $\pm 1.5 \mathrm{~m} \mathrm{y}^{-1}$, which can characterize the maintenance of the sedimentary balance along the three analyzed decades.

Table 2. Comparative annual rates of shoreline change using the transectfrom-baseline (DSAS) and change polygon method (CPM).

\begin{tabular}{ccc}
\hline \hline $\begin{array}{c}\text { Time } \\
\text { Interval }\end{array}$ & $\begin{array}{c}\text { Transect-from-Baseline } \\
\left(\mathrm{m} \mathrm{y}^{-1}\right)\end{array}$ & $\begin{array}{c}\mathrm{CPM} \\
\left(\mathrm{m} \mathrm{y}^{-1}\right)\end{array}$ \\
\hline $1984-1988$ & -1.54 & -1.50 \\
$1988-1995$ & +3.89 & +3.93 \\
$1995-2001$ & -2.21 & -2.16 \\
$2001-2005$ & +4.32 & +4.34 \\
$2005-2009$ & -0.75 & -0.60 \\
$2009-2013$ & -0.21 & -0.46 \\
$1984-2013$ & +0.729 & +0.734 \\
\hline
\end{tabular}

In the last three decades, Vitoriano spit had undergone significant morphological changes. Therefore, this spit was selected to exemplify the morphological behavior of these coastal features along the central landward margin of Lagoa dos Patos lagoon during this time (Figure 5).

During the analyzed time period, sandbanks were observed emerging from the subaqueous sandbars with a tendency to landward migration. From 1984 to 1988, the proximal and the outermost sandbanks lost 39.9 and $7.8 \mathrm{~km}^{2}$ of area, respectively (Figure 5a). In the subsequent time span (19881995), the updrift coast of Vitoriano spit retreated while the distal end of the spit prolonged toward the approaching sandbank (Figure 5b). Between 1995 and 2001, the larger and nearest sandbank joined the emerged spit, changing its shape and morphology and resulting in a high sand accumulation of $21.5 \mathrm{~km}^{2}$ of area at the eastern edge of the 


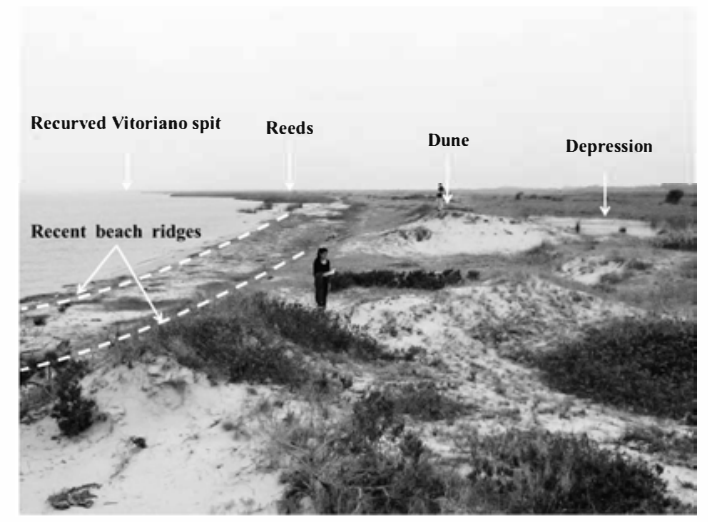

Figure 6. Growth of recent beach ridges at the sheltered updrift coast of the Vitoriano spit.

emerged spit, associated with a northern sandbank with an area of $45.8 \mathrm{~km}^{2}$ (Figure 5c). From 2001 to 2005, higher sand accumulation was observed $\left(82.6 \mathrm{~km}^{2}\right)$, and the Vitoriano spit acquired a recurved shape and showed onshore migration. Moreover, another two sandbanks $\left(29.0\right.$ and $\left.4.1 \mathrm{~km}^{2}\right)$ were built up from the submerged sandbar (Figure $5 \mathrm{~d}$ ). Between 2005 and 2009, the onshore migration of the current recurved spit continued, together with the elongation of its northern end and the obstruction of sediment at its southern distal edge $\left(30.5 \mathrm{~km}^{2}\right)$ (Figure 5e). From 2009 to 2013, the high sediment accumulation in the southern edge of the spit continued, whereas the north "hook" lost an area of $48.4 \mathrm{~km}^{2}$, which was deposited as a shoal (Figure 5f). Moreover, the growth of new beach ridges was also observed (Figure 6).

The sandbank buildup process and subsequent landward migration over the submerged bars of the sandy spits, eroding and accreting while migrating and merging into the spit's shoreline, were also observed for the others two spits (Appendices A and B).

\section{Medium-Term Shoreline Assessment (EPR and LRR)}

From 1984 to 2013, the EPR statistic depicted stable values (within the uncertainty error of $\pm 1.5 \mathrm{~m} \mathrm{y}^{-1}$ ), accounting for $84.3 \%$ of Arambaré and $78.3 \%$ of Graxaim coastlines. Less frequent low progradation rates (from +1.5 to $+3.0 \mathrm{~m} \mathrm{y}^{-1}$ ) along the northern half part of the bay beaches were observed, accounting for $14.2 \%$ of Arambaré and $18.7 \%$ of Graxaim (Figure 7a). However, the LRR statistic depicted a higher occurrence of low progradation rates (Figure 7b), especially for the Arambaré coastline, which showed $37.6 \%$ low progradation rates $\left(+1.5\right.$ to $\left.+3.0 \mathrm{~m} \mathrm{y}^{-1}\right)$ and $60.4 \%$ stability. Graxaim continued presenting the dominant behavior of shoreline stability (73.9\%), with $20.9 \%$ low depositional rates.

On Arambaré, moderate shoreline progradation, ranging from +3.0 to $+4.4 \mathrm{~m} \mathrm{y}^{-1}$, was observed at the Velhaco mouth and inlets 2 and 3 , up to a maximum of $+6.2 \mathrm{~m} \mathrm{y}^{-1}$ at the accentuated curvature of shoreline between the northern embayment and southern margin of Dona Helena spit (Figure 7b.1). Retreat rates were observed in the right margin of Lagoa do Graxaim inlet (ranging from -1.7 to $-2.5 \mathrm{~m} \mathrm{y}^{-1}$ for the EPR statistic and from -1.9 to $-2.8 \mathrm{~m} \mathrm{y}^{-1}$ for LRR), whereas a deposition rate of $+2.4 \mathrm{~m} \mathrm{y}^{-1}$ was observed by LRR at its northern margin, showing the southward migration of the inlet.

Furthermore, low to moderate retreat rates, ranging from -1.7 up to $-4.6 \mathrm{~m} \mathrm{y}^{-1}$, were observed at the northern distal end of Dona Maria spit by both applied statistics (Figure 7b.2).

On Graxaim, moderate shoreline progradation ranging from +3.0 to $6.0 \mathrm{~m} \mathrm{y}^{-1}(2.4 \%$ by EPR and $2.9 \%$ by LRR) were observed at inlet 5 and along the shoreline indentations close to inlets 4 and 5. The LRR analysis indicates shoreline retreat at the extreme south of Graxaim bay beach in the attachment sector with Vitoriano spit, ranging from -1.6 to $-1.8 \mathrm{~m} \mathrm{y}^{-1}$, which accounts for $1.6 \%$ of Graxaim shoreline.

Accentuated and localized high depositional values (ranging from +6.0 to $+9.5 \mathrm{~m} \mathrm{y}^{-1}$ ) were observed at the mouth of inlet 4 . Moderate to high progradation rates, from +3.4 up to $+14.6 \mathrm{~m}$ $\mathrm{y}^{-1}$, were observed at the distal end of Vitoriano spit (Figure 7b.3). Overall, no representative retreat rates were observed in the medium-term shoreline assessment of the bay beaches.

\section{DISCUSSION}

Satellite remote sensing data has been widely used for automatic or semiautomatic coastline identification. In particular, much work exploited Landsat TM data by applying different analysis techniques (Guariglia et al., 2006). Limitations, such as the relatively coarse spatial resolution $(30 \mathrm{~m})$, are mitigated by their synoptic, multitemporal, and multispectral information (Cenci et al., 2013; Niya et al., 2013). For the present work, the spectral characteristics of the Landsat satellite images allowed the use of near-infrared, blue, and green RGB composite bands to delimit the wet/dry land boundary with more confidence and replicability. The use of Landsat satellite images to measure and spatially analyze the coastal changes over a period of decades has been a common practice over the last decades (Alves, Amaro, and Vital, 2003; Appeaning Addo, Jayson-Quashigah, and Kufogbe, 2011; Cenci et al., 2013; Ghanavati et al., 2008; Gisp, 2014; Kumar, Deepika, and Jayappa, 2013; Kumar, Narayana, and Jayappa, 2010; Niya et al., 2013; Noernberg and Marone, 2003; White and El Asmar, 1999; Yang and Ouchi, 2010).

The transect-from-baseline method has been used by many researchers and agencies as the standard method to determine long-term coastal change rates and coastal hazard zones (Crowell, Leatherman, and Buckley, 1991). On the other hand, Smith and Cromley (2012) suggested that the polygon technique may be a more robust method, being less invariant to parameter changes. The main drawbacks and advantages pointed out by Thieler et al. (2009), Smith and Cromley (2012), Albuquerque et al. (2013), and this study are summarized in Table 3.

For the present research, the use of two different methods has proven to be complementary. The transect-based method allowed better control of shoreline movement of the bay beaches, and CPM allowed the complete measurement of area changes of the spits and associated sandbanks. Furthermore, for the transect-based method, no large differences were observed between the range (maximum and minimum rates) of the EPR and LRR results. However, the LRR algorithm identified a larger stretch of prograding shoreline because of the increased amount of shoreline data considered. 


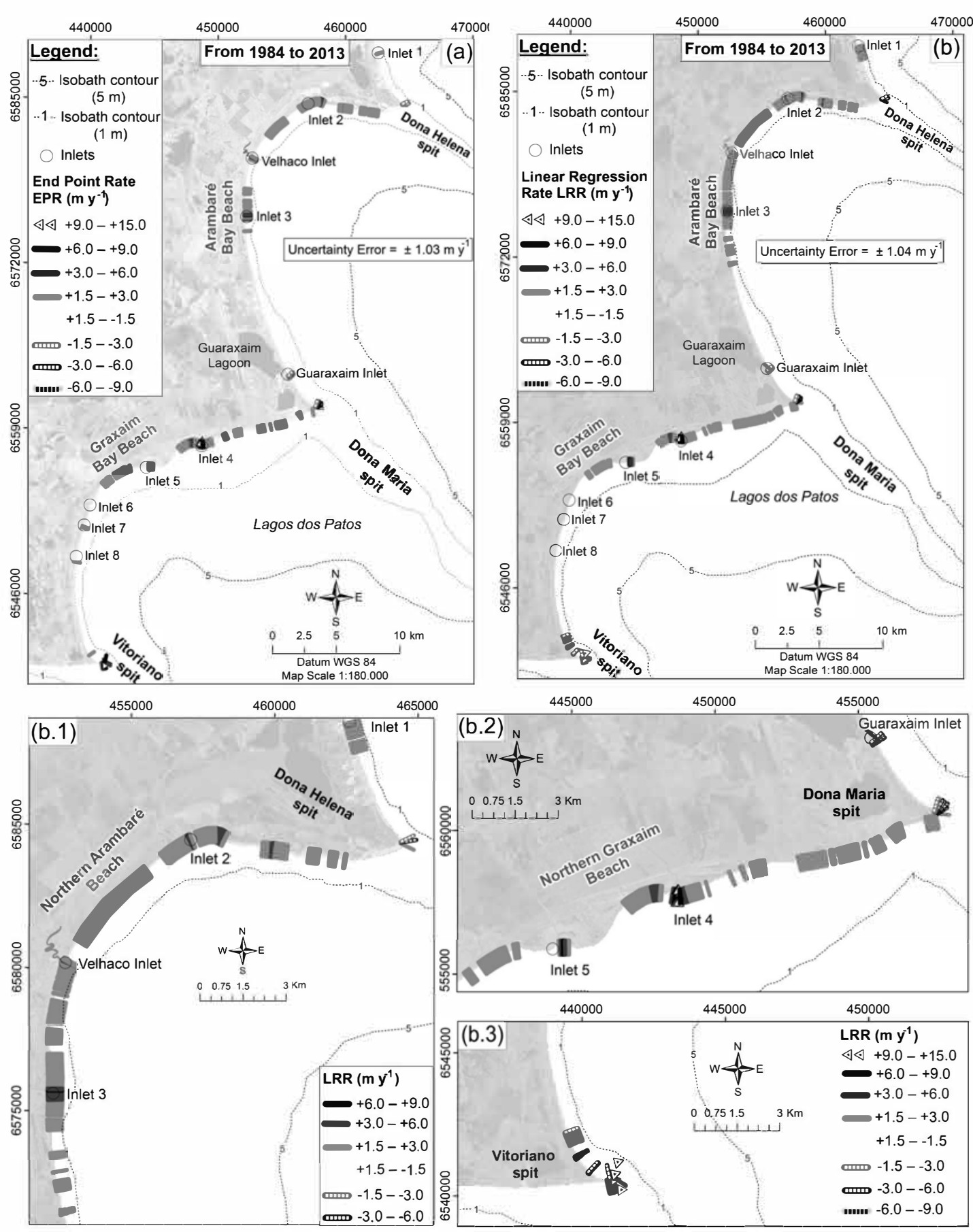

Figure 7. Annual rate of shoreline change for the medium-term analysis using: (a) EPR and (b) LRR statistics, with magnified portions of the northern Arambaré beach (b.1), the northern coast of Gracaim (b.2), and the coastline of Vitoriano spit (b.3). Image source: Landsat 5.

\section{Medium-Term and Short-Term Shoreline Assessments}

When analyzing short-term shoreline variability, a dominant stability trend $(>80 \%)$ of the bay beaches was observed from 1984 to 1988 , from 2005 to 2009 , and from 2009 to 2013 . These periods were coincident with neutral Southern Annular Mode phases and greater correlation with the precipitation patterns over the central region of the Rio Grande do Sul coastal plain, including Lagoa dos Patos. Furthermore, during these periods, a weak El Niño (2009) and moderate (2010-2011) and weak (2012) La Niña years occurred, which resulted in low- 
Table 3. Advantages and disadvantages of the statistics applied by the transect-from-baseline (DSAS) method vs. the change polygon method.

\begin{tabular}{|c|c|c|}
\hline Method & Advantages & Disadvantages \\
\hline $\begin{array}{l}\text { Transect-from-baseline } \\
\text { (DSAS) }\end{array}$ & $\begin{array}{l}\text { Includes all shoreline data available in the final } \\
\text { computation by the LRR statistic. } \\
\text { Automatic and local assessment of shoreline } \\
\text { movement. } \\
\text { Provides better control and monitoring of local } \\
\text { coastal changes by densely distributed shore- } \\
\text { parallel transects. }\end{array}$ & $\begin{array}{l}\text { Large lengths of the shoreline may be omitted in the } \\
\text { measurement processes (Smith and Cromley, 2012). } \\
\text { The average change rate brings residuals from regions } \\
\text { that are not reached by the transects (Albuquerque } e t \\
\text { al., 2013). } \\
\text { Solution: Higher spatial resolution between transects. } \\
\text { The choice of a proper baseline (Smith and Cromley, } \\
\text { 2012). } \\
\text { Transects can intersect each other and do not reach the } \\
\text { nearest shoreline (Smith and Cromley, 2012). } \\
\text { Solution: Depending on coastal indentation, transects } \\
\text { need to be carefully checked. }\end{array}$ \\
\hline $\begin{array}{l}\text { Change Polygon Method } \\
\text { (Smith and Cromley, 2012) }\end{array}$ & $\begin{array}{l}\text { Area analysis (Smith and Cromley, 2012). } \\
\text { Allows the quantification of morphological changes } \\
\text { for which it is not possible to use the same } \\
\text { baseline of reference }(e . g ., \text { sandbank migration } \\
\left.\text { and recurved spit, in } \mathrm{m}^{2}\right) \text {. }\end{array}$ & $\begin{array}{l}\text { Low localized control on the monitoring of the shoreline } \\
\text { change rates. } \\
\text { Sensitive to the definition of the shoreline length used as } \\
\text { denominator in the measurement of the net change } \\
\text { area (Smith and Cromley, 2012). } \\
\text { Does not account for more than two shoreline vectors in } \\
\text { the annual rate of change. }\end{array}$ \\
\hline
\end{tabular}

precipitation anomalies (Schossler et al., 2018). Allied to this, discharge values below the average were registered during the La Niña period (Vaz, Moller, and Almeida, 2006). This scenario, in turn, resulted in a prevalence of steady hydrodynamic conditions over the lagoon margins.

From 1988 to 1995, a representative shoreline progradation was observed, accounting for $51 \%$ of the Arambaré coastline and $31.3 \%$ of Graxaim, with depositional rates mainly concentrated on its northern sector. On the other hand, the southern extremity (the updrift coast of Vitoriano spit) retreated along with the prolongation of the distal end of Vitoriano spit $(+13.7 \mathrm{~m}$ $\mathrm{y}^{-1}$ ) toward the sheltered area of the approaching sandbank (Figure 3b). Ashton, Nienhuis, and Ells (2016, p. 193) highlighted that the rate of sediment input to the spit itself emerges through feedback with the downdrift spit end, so that "faster spit progradation may coincide with reduced sediment input to the spit itself." In this case, this process may be locally intensified by changes in the wave diffraction-refraction patterns promoted by the adjacent sandbar.

In the subsequent time span (1995-2001) the adjacent sandbank migrated onshore, reducing area and joining to Vitoriano spit (Figure 5c), which resulted in a high progradation rate of the spit $\left(+12.8 \mathrm{~m} \mathrm{y}^{-1}\right)$ (Figure 3c). Besides the predominant occurrence of shoreline stability during this period $(77.8 \%$ of Arambaré beach and $90.8 \%$ of Graxaim embayment), Arambaré experienced significant shoreline retraction (21.4\%) in the southern half of its coast (Figure 3c). This period was marked by a peak in precipitation anomalies, concomitant with a very strong El Niño phase from 1997 to 1998 (Schossler et al., 2018) and intense hydrodynamic conditions from an increased freshwater discharge at the top of the lagoon (Fernandes et al., 2002). Together with the occurrence of 20 registered cases of storm surges on the adjacent coast associated with extratropical cyclones, from 1997 to 1999, and winds from the SE, SW, and SSW directions and speeds of 16 to $24 \mathrm{~m} \mathrm{~s}^{-1}$ (Saraiva, Bedran, and Carneiro, 2003). This scenario may have contributed to higher wind waves in the lagoon and the consequent erosion pattern observed in the downcoast sector of Arambaré bay beach, transporting sediment northward.

The following time interval (2001-2005) was a period of overall depositional trend, with $55.9 \%$ of shoreline progradation in the center and the southern part of Arambaré bay beach, along with a smaller percentage of progradation rate values at Graxaim embayment (12.5\%), mainly along irregularities of the shoreline next to inlets 4 and 5 and near the southern margin of Dona Maria spit (Figure 4a). In contrast with the previous time interval, this suggests an interannual exchange of sediments between the beach extremities.

Medium-term analyses of shoreline trend demonstrate that Arambaré and Graxaim beaches remained relatively stable. The EPR analysis showed the predominant stability for both bay beaches, and the LRR depicted greater extension of the shoreline $(9.47 \mathrm{~km}$ ) with low progradation rates (Figure 7$)$. The absence of representative retreat rates throughout the bay beaches (the main source of sediments) shows the limited sediment supply to the continuous growth of the spits, once it is assumed that embayment erosion from the accentuated littoral drift resulting from the dominant approach of oblique wave angles is the main process responsible for the growth of the spit features.

Therefore, the analyzed bay beaches are under a stabilization process while the submerged bars of the spits are sedimentstarved, leading to the cannibalization of proximal regions of the sandbars, accompanied by the up-building of sandbanks. Once emerged, landward migration of the sandbanks over the submerged sandbars was observed, ending with a merging with the mainland (Figure 5). The case of Vitoriano spit resulted in the development of a recurved shape that trapped the littoral drift from the northern and southern margins of the spit and resulted in the growth of incipient beach ridges on the northern shore (Figure 6). These beach ridges likely were built by the net longshore transport to the south on the west embayments, as observed by Toldo et al. (2006), who relate the net longshore transport with the wind-wave action generated by the predominant $\mathrm{NE}$ winds during summer and spring. 
Moreover, the landward migration of the recurved Vitoriano spit highlights the importance of the cross-shore transport effects, despite the longshore sediment transport being the dominant component of the lagoon embayment-spit system.

\section{CONCLUSIONS}

The two methods applied to quantify and analyze shoreline changes (transect-from-baseline and CPM) are found not to be exclusionary, but complementary. The overall annual rates of shoreline change were very similar by both methods. The transect-from-baseline method provided robust results with regard to the local behavior of shoreline movement by using equally spaced transects and including all the coastline vectors available in the longest period of shoreline change measurement (by LRR statistic), which allowed the detailed analyses of shoreline behavior for Arambaré and Graxaim bay beaches.

The CPM presented better results for analyzing the up-build process of sandbanks and their landward migration along the submerged bars. Although Landsat images are not particularly recommended for quantifying shoreline change rates in short time periods, the results presented here allowed the interannual analysis of beach variabilities associated with the cyclogenesis of local climatic aspects, in which the neutral Southern Annular Mode phases associated with weak El Niño and weak and moderate La Niña years were coincident with the predominant stable behavior of the coastline, whereas a higher occurrence of shoreline retraction was observed during very strong El Niño periods. A better control in regard to the frequency and direction of storm winds and related hydrodynamic conditions in the lagoon waterbody (e.g., wave energy distribution) is recommended in the literature to further explain the spatial variability of shoreline recession and progradation trends because of the variable orientation of the shoreline.

In the medium term, from 1984 to 2013 , the two analyzed beaches did not show representative recessional rates by either statistic (EPR or LRR). Additionally, the average change rate of approximately $+0.7 \mathrm{~m} \mathrm{y}^{-1}$ (which is within the uncertainty error of $\pm 1.5 \mathrm{~m} \mathrm{y}^{-1}$ ) found by both methods (transect-frombaseline and CPM) reinforce that no erosional trends were observed in the longest period.

Therefore, the lagoon sandy spits in the central west margin of Lagoa dos Patos are growth-limited by a reduced sediment supply from the adjacent beaches, and the submerged bars have been providing sediment to the emerged spit coastline during the last three decades.

\section{ACKNOWLEDGMENTS}

The authors acknowledge PFHR-Petrobras, PB-215, for the funding of a student grant during the development of this work, as well as the Centro de Estudos de Geologia Costeira e Oceânica-(CECO)/UFRGS and the Laboratório de Oceanografia Costeira-(LOC)/UFSC for the infrastructure and good work environment.

\section{LITERATURE CITED}

Albuquerque, M.; Espinoza, J.; Teixeira, P.; Oliveira, A.; Corrêa, I., and Calliari, L., 2013. Erosion or coastal variability: An evaluation of the DSAS and the change polygon methods for the determination of erosive processes on sandy beaches. In: Conley, D.C.; Masselink, G.; Russell, P.E., and O'Hare, T.J. (eds.), Proceedings from the International Coastal Symposium (ICS) 2013. Journal of Coastal Research, Special Issue No. 65, pp. 1710-1714. doi:10.2112/SI65-289. 1

Alves, A.L.; Amaro, V.E., and Vital, H., 2003. Multitemporal analysis of multispectral Landsat 5-Thematic Mapper images for monitoring and evaluation of coastal morphodynamic on the northeastern coast of Brazil. In: Klein, A.H.F.; Finkl, C.W.; Rorig, L.R.; Santana, G.G.; Diehl, F.L., and Calliari, L.J. (eds.), Proceedings of the Brazilian Symposium on Sandy Beaches: Morphodynamics, Ecology, Uses, Hazards and Management. Journal of Coastal Research, Special Issue No. 35, pp. 279-283.

Appeaning Addo, K.; Jayson-Quashigah, P.N., and Kufogbe, K.S., 2011. Quantitative analysis of shoreline change using medium resolution satellite imagery in Keta, Ghana. Marine Science, 1(1), 1-9. doi:10. 5923/j.ms.20110101.01

Appeaning Addo, K.; Walkden, M., and Mills, J.P., 2008. Detection, measurement, and prediction of shoreline recession in Accra, Ghana. ISPRS Journal of Photogrammetry and Remote Sensing, 63(5), 543558. doi:10.1016/j.isprsjprs.2008.04.001

Ashton, A.; Murray, A.B., and Arnault, O., 2001. Formation of coastline features by large-scale instabilities induced by high-angle waves. Nature, 414(6861), 296-300. doi:10.1038/35104541

Ashton, A.; Nienhuis, J., and Ells, K., 2016. On a neck, on a spit: Controls on the shape of free spits. Earth Surface Dynamics, 4, 193210. doi:10.5194/esurfd-4-193-2016

Ashton, A.D.; Murray, A.D.; Littlewood, R.; Lewis, D.A., and Hong, P., 2009. Fetch-limited self-organization of elongate water bodies. Geology, 37(2), 187-190. doi:10.1130/G25299A.1

Bouchette, F.; Manna, M.; Montalvo, P.; Nutz, A.; Schuster, M., and Ghienne, J.F., 2014. Growth of cuspate spits. In: Green, A.N. and Cooper, J.A.G. (eds.), Proceedings from the International Coastal Symposium (ICS) 2014. Journal of Coastal Research, Special Issue No. 70, pp. 47-52. doi:10.2112/SI70-009.1

Cenci, L.; Disperati, L.; Souza, L.P.; Phillips, M., and Alves, F.L., 2013. Geomatics for integrated coastal zone management: Multitemporal shoreline analysis and future perspective for the Portuguese Central Region. In: Conley, D.; Masselink, G.; Russel, P., and O'Hare, T. (eds.), Proceedings from the International Coastal Symposium (ICS) 2013. Journal of Coastal Research, Special Issue No. 65, pp. 13491354. doi:10.2112/SI65-228.1

Crowell, M.; Douglas, B., and Leatherman, S.P., 1997. On forecasting future U.S. shoreline positions: A test of algorithms. Journal of Coastal Research, 13(4), 1245-1255.

Crowell, M.; Leatherman, S.P., and Buckley, M.K., 1991. Historical shoreline change: Error analysis and mapping accuracy. Journal of Coastal Research, 7(3), 839-852.

Dan, S.; Walstra, D.R.; Stive, M.J., and Panin, N., 2011. Process controlling the development of a spit river mouth. Marine Geology, 280(1-4), 116-129.

Dar, I.A. and Dar, M., 2009. Prediction of shoreline recession using geospatial technology: A case study of Chennai Coast, Tamil Nadu, India. Journal of Coastal Research, 25(6), 1276-1286. doi:10.2112/ JCOASTRES-D-09-0051.1

Fenster, M.S.; Dolan, R., and Elder, J.F., 1993. A new method for predicting shoreline positions from historical data. Journal of Coastal Research, 9(1), 147-171.

Fernandes, E.H.L.; Dyer, K.R.; Moller, O.O., and Niencheski, L.F.H., 2002. The Patos Lagoon hydrodynamics during an El Niño event (1998). Continental Shelf Research, 22(11-13), 1699-1713.

Fernandes, E.H.L.; Mariño-Tapia, I.; Dyer, K.R., and Moller, O.O., 2004. The attenuation of tidal and subtidal oscillations in the Patos Lagoon estuary. Ocean Dynamics, 54(3-4), 348-359. doi:10.1007/ s10236-004-0090-y

Fisher, R.L., 1955. Cuspate spits of St. Lawrence Island, Alaska. Journal of Geology, 63(2), 133-142.

Fletcher, C.H.; Romine, B.M.; Genz, A.S.; Barbee, M.M.; Dyer, M.; Anderson, T.R.; Lim, S.C.; Vitousek, S.; Bochicchio, C., and Richmond, B.M., 2012. National Assessment of Shoreline Change: Historical Shoreline Change in the Hawaiian Islands. Reston, Virginia: U.S. Geological Survey, Open-File Report 2011-1051, 55p. 
Galgano, F.A. and Douglas, B.C., 2000. Shoreline position prediction Methods and errors. Environmental Geosciences, 7(1), 23-31. doi:10. 1046/j.1526-0984.2000.71006.x

Gens, R., 2010. Remote sensing of coastlines: Detection, extraction, and monitoring. International Journal of Remote Sensing, 31(7), 18191836. doi:10.1080/01431160902926673

Ghanavati, E.; Firouzabati, P.Z.; Jangi, A.A., and Khosravi, S., 2008 Monitoring geomorphologic changes using Landsat TM and ETM data in the Hendijan River delta, southwest Iran. Internationa Journal of Remote Sensing, 29(4), 945-959. doi:10.1080/ 01431160701294679

Gilbert, G.K., 1885. The Topographic Features of Lake Shores. Washington, D.C.: U.S. Geological Survey, Fifth Annual Report, pp. 69-123.

Gisp, R.C.D., 2014. Using ArcMap to extract shorelines from Landsat TM \& ETM+ data. Proceedings of the Thirty-second ESRI International Users Conference (San Diego, California), pp. 1-23.

Guariglia, A.; Buonamassa, A.; Losurdo, A.; Saladino, R.; Trivigno, M.L.; Zaccagnino, A., and Colangelo, A., 2006. A multisource approach for coastline mapping and identification of shoreline changes. Annals of Geophysics, 49(1), 295-304. doi:10.4401/ag-3155

Hasenack, H. and Ferraro, L.W., 1989. Considerações sobre o clima da região de Tramandaí, RS. Pesquisas em Geociências, 22(22), 53-70.

Jonah, F.E.; Boateng, I.; Osman, A.; Shimba, M.J.; Mensah, E.A.; AduBoahen, K.; Chuku, E.O., and Effah, E., 2016. Shoreline change analysis using end point rate and net shoreline movement statistics: An application to Elmina, Cape Coast and Moree section of Ghana's coast. Regional Studies in Marine Science, 7, 19-31. doi:10.1016/j. rsma.2016.05.003

Kjerve, B. and Magill, K., 1989. Geographic and hydrodynamic characteristics of shallow coastal lagoons. Marine Geology, 88(3-4), 187-199. doi:10.1016/0025-3227(89)90097-2

Kraus, N.C., 1999. Analytical model of spit evolution at inlets. Proceedings of Coastal Sediments 99 (Long Island, New York, ASCE), pp. 1739-1754.

Kumar, A.; Deepika, B., and Jayappa, K.S., 2013. Evolution of spit morphology: A case study using remote sensing statistical based approach. Journal of Coastal Conservation, 17(3), 327-337. doi:10. 1007/s11852-013-0259-y

Kumar, A.; Narayana, A.C., and Jayappa, K.S., 2010. Shoreline changes and morphology of spits along southern Karnataka, west coast of India: A remote sensing and statistics-based approach. Geomorphology, 120(3), 133-152. doi:10.1016/j.gemorph.2010.02.023

Moller, O.O.; Castaing, P.; Salomon, J.C., and Lazure, P., 2001. The influence of local and non-local forcing effects on the subtidal circulation of Patos Lagoon. Estuaries, 24(2), 297-311.

Moller, O.O.; Lorenzzentti, J.A.; Stech, J.L., and Mata, M.M., 1996. The Patos Lagoon summertime circulation and dynamics. Continental Shelf Research, 16(3), 335-351. doi:10.1016/0278-4343(95)00014-R

Niya, A.K.; Alesheikh, A.A.; Soltanpor, M., and Kheirkhazarkesh M.M., 2013. Shoreline change mapping using remote sensing and GIS. International Journal of Remote Sensing Applications, 3(3) 102-107.

Noernberg, M.A. and Marone, E., 2003. Spatial-temporal monitoring of the Paranaguá Bay inlet margins using multispectral Landsat-TM images. In: Klein, A.H.F.; Finkl, C.W.; Rorig, L.R.; Santana, G.G.; Diehl, F.L., and Calliari, L.J. (eds.), Proceedings of the Brazilian Symposium on Sandy Beaches: Morphodynamics, Ecology, Uses, Hazards and Management. Journal of Coastal Research, Special Issue No. 35, pp. 221-231.

Pajak, M.J. and Leatherman, S., 2002. The high water line as shoreline indicator. Journal of Coastal Research, 18(2), 329-337.

Petersen, D.; Deigaard, R., and Fredsoe, J., 2008. Modelling the morphology of sandy spits. Coastal Engineering, 55(7-8), 671-684. doi:10.1016/j.coastaleng.2007.11.009

Randazzo, G.; Jackson, D.W.T., and Cooper, J.A., 2015. Sand and Gravel Spits. London: Springer, 344p.
Rosen, P.S., 1975. Origin and processes of cuspate spit shorelines. In: Cronin, L.E. (ed.), Estuarine Research, Volume 2, Geology and Engineering. New York: Academic, pp. 77-92. doi:10.13140/2.1.3070. 7208

Saraiva, J.M.B.; Bedran, C., and Carneiro, C., 2003. Monitoring storm surges on Cassino Beach, RS, Brazil. In: Klein, A.H.F.; Finkl, C.W Rorig, L.R.; Santana, G.G.; Diehl, F.L., and Calliari, L.J. (eds.), Proceedings of the Brazilian Symposium on Sandy Beaches Morphodynamics, Ecology, Uses, Hazards and Management. Journal of Coastal Research, Special Issue No. 35, pp. 323-331.

Schossler, V.; Simões, J.C.; Aquino, F.E., and Viana, D.R., 2018 Precipitation anomalies in the Brazilian southern coast related to the SAM and ENSO climate variability modes. Brazilian Journal of Water Resources, 23(14), 1-10.

Shepard, F.P., 1952. Revised nomenclature for depositional coastal features. Bulletin of the Association of Petroleum Geologists, 36(10) 1902-1912.

Smith, M.J. and Cromley, R.G., 2012. Measuring historical coastal change using GIS and the changes polygon approach. Transaction in GIS, 16(1), 3-15. doi:10.1111/j.1467-9671.2011.01292.x

Thieler, E.R.; Himmelstoss, E.A.; Zichichi, J.L., and Ergul, A., 2009 Digital Shoreline Analysis System (DSAS) Version 4.0-An ArcGIS Extension for Calculating Shoreline Change. Woods Hole, Massachusetts: U.S. Geological Survey, Open-File Report No. 2008-1278, $81 \mathrm{p}$.

Toldo, E.E., Jr., 1991. Morfodinâmica da Laguna dos Patos, Rio Grande do Sul. Pesquisas em Geociências, 18(1), 58-63.

Toldo, E.E., Jr.; Almeida, L.E.S.B., and Corrêa, I.C.S., 2003. Forecasting shoreline changes of Lagoa dos Patos lagoon, Brazil. In: Klein, A.H.F.; Finkl, C.W.; Rorig, L.R.; Santana, G.G.; Diehl, F.L., and Calliari, L.J. (eds.), Proceedings of the Brazilian Symposium on Sandy Beaches: Morphodynamics, Ecology, Uses, Hazards and Management. Journal of Coastal Research, Special Issue No. 35, pp. 43-50.

Toldo, E.E., Jr.; Almeida, L.E.S.B.; Corrêa, I.C.S.; Ferreira, E.R., and Gruber, N.L.S., 2006. Wave prediction along Lagoa dos Patos coastline, southern Brazil. Atlântica (Rio Grande), 28(2), 87-95.

Toldo, E.E., Jr.; Dillenburg, S.R.; Corrêa, I.C.S., and Almeida, L.E., 2000. Holocene sedimentation in Lagoa dos Patos Lagoon, Rio Grande do Sul, Brazil. Journal of Coastal Research, 16(3), 816-822

Tomazelli, L.J.; Dillenburg, S.R., and Villwock, J.A., 2004. Geological evolution of Rio Grande do Sul coastal plain, southern Brazil. In: Klein, A.H.F.; Santana, G.G.; Rorig, L.R.; Finkl, C.W.; Diehl, F.L., and Calliari, L.J. (eds.), Proceedings from the International Coastal Symposium (ICS) 2004. Journal of Coastal Research, Special Issue No. 39 , pp. 275-278.

Uda, T., 2015. Numerical simulation of formation of cuspate foreland behind an offshore breakwater built in a lake. Procedia Engineering, 116, 478-485. doi:10.1016/j.proeng.2015.08.316

Vaz, A.C.; Moller, A.A., and Almeida, T.L., 2006. Análise quantitative da descarga dos rios afluentes da Lagoa dos Patos. Atlântica (Rio Grande), 28(1), 13-23.

Vieira da Silva, G.; Muler, M.; Prado, M.F.V.; Short, A.D.; Toldo, E.E., Jr., and Klein, A.H.F., 2016. Shoreline changes analysis and insights into sediment transport path-Example of Santa Catarina Island North Shore, Brazil. Journal of Coastal Research, 32(4), 863-874.

White, K. and El Asmar, H.M., 1999. Monitoring changing position of coastlines using Thematic Mapper imagery, an example from the Nile Delta. Geomorphology, 29(1-2), 93-105. doi:10.1016/S0169$555 x(99) 00008-2$

Yang, C. and Ouchi, K., 2010. Analysis of bar morphology using multitemporal and multi-sensor satellite images: Example from the Han estuary, Korea. Marine Geology, 311-314, 17-31. doi:10.1006/j. margeo.2012.04.004

Zenkovitch, V.P., 1959. On the genesis of the cuspate spits along lagoon shores. The Journal of Geology, 67(3), 269-277. 


\section{APPENDIX A}

Study case of the decadal coastal morphological evolution of Dona Helena spit, showing sandbar up-building, followed by landward migration and merging to the spit shorelines: (a) 1984-1988, erosion of the south margin of Dona Helena spit; (b) 1988-1995, up-building of two sandbanks of $4435.4 \mathrm{~m}^{2}$ and $11,369.8 \mathrm{~m}^{2}$ next to the edge of Dona Helena spit; (c) 1995-2001, erosion of the sandbank and the northern coast of the spit; (d) 2001-2005, approach of the sandbank observed in 1995; (e) 2005-2009, merging of the sandbank to the spit's shoreline; (f) 2009-2013, erosion of the distal end and the northern coast of the spit again.
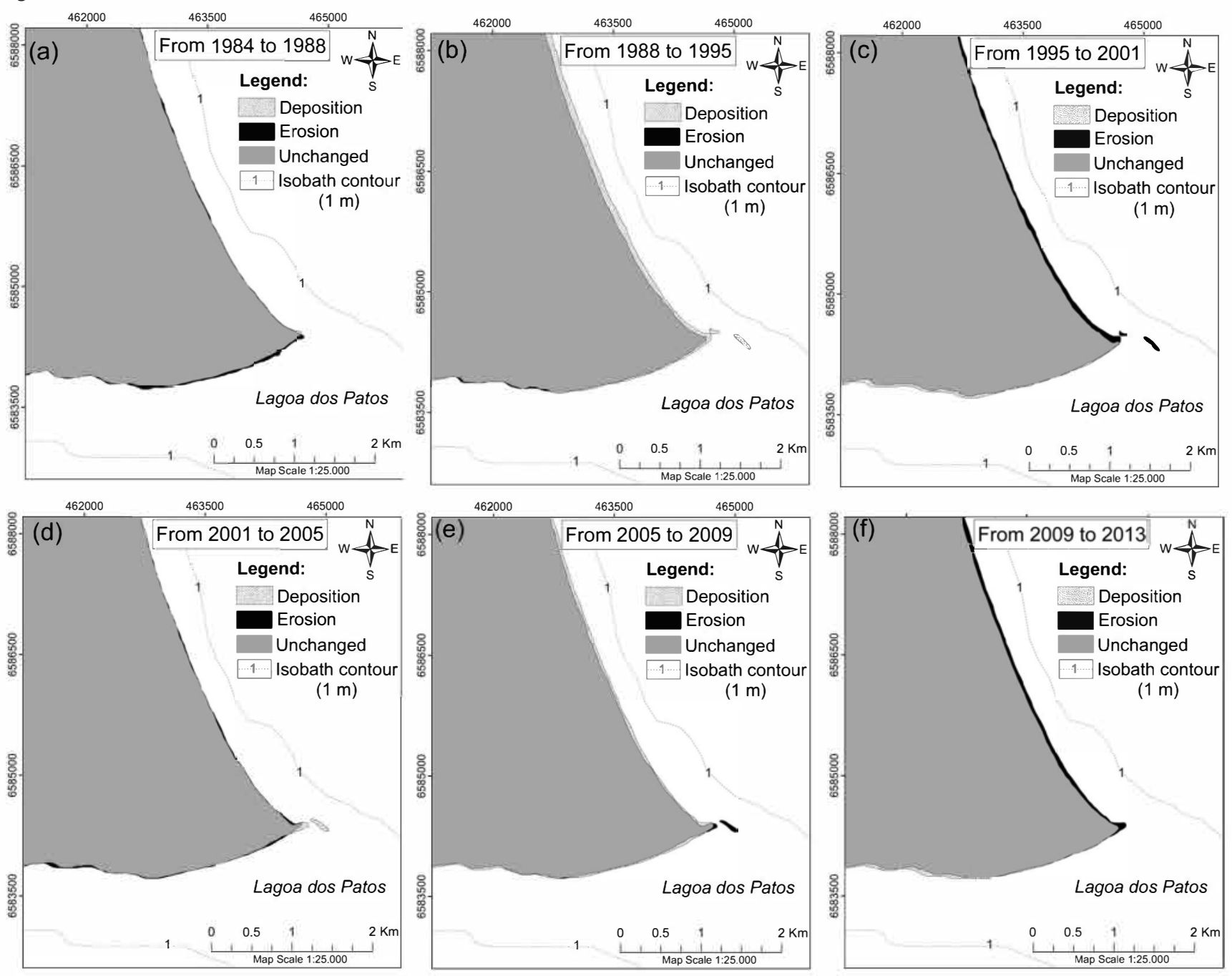


\section{APPENDIX B}

Study case of the decadal morphological evolution of Dona Maria spit into six time spans from 1984 to 2013, emphasizing the general trend of sandbar upbuilding and subsequent shoreward migration and merging to the spit shoreline: (a) 1984-1998, erosion in the adjacent 28,200-m ${ }^{2}$ sandbar ; (b) 1988-1995, welding of the eroded sandbank observed in the previous time span; (c) 1995-2001, erosion of the distal end and the northern coast of the spit; (d) 2001-2005, emergence and approach of another 25,264.9- $\mathrm{m}^{2}$ sandbank; (e) 2005-2009, joining of the sandbank to the spit shoreline and up-building of another 6734.3-m sandbank; (f) 2009-2013, erosion of the distal end and the northern coast.
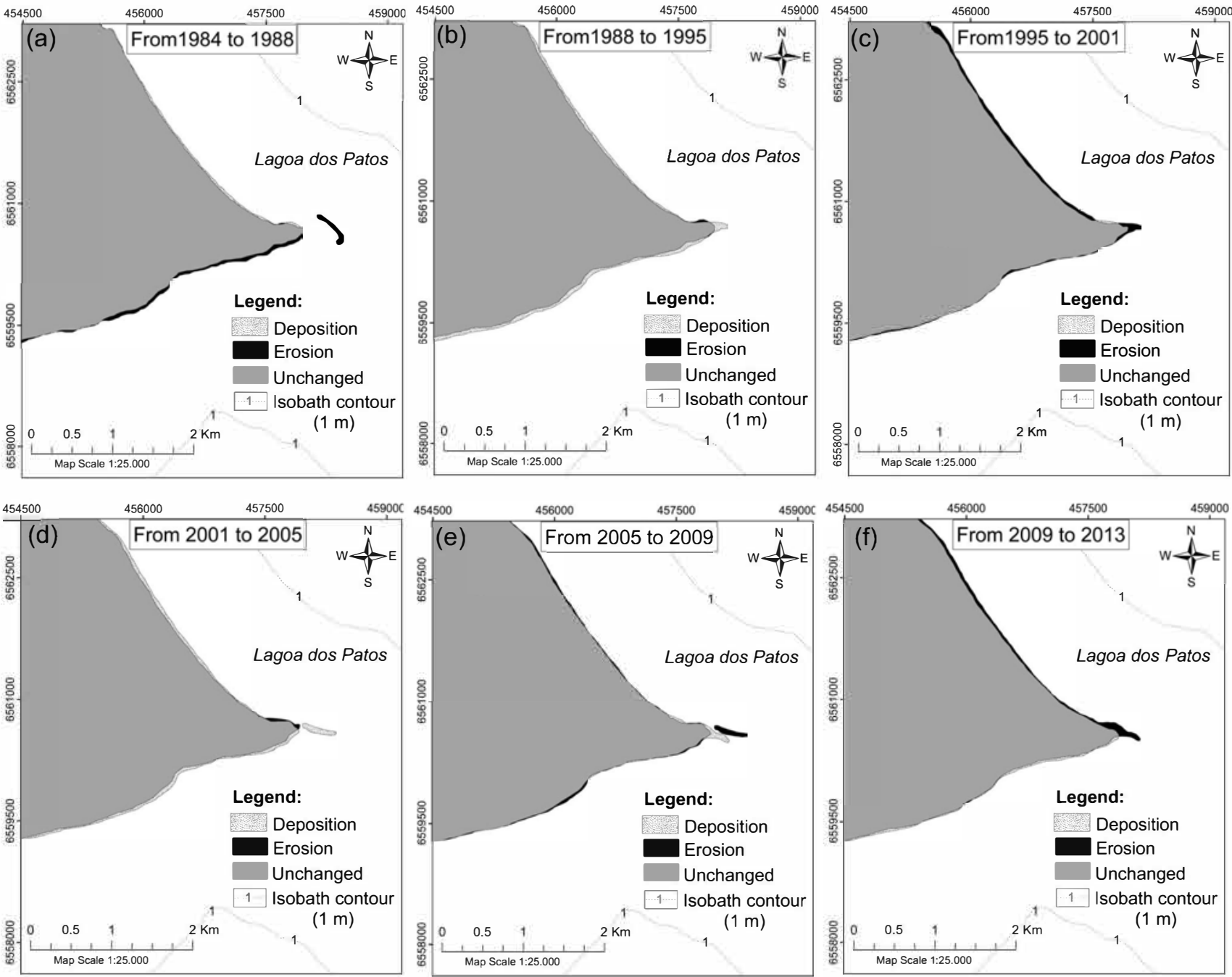